\title{
MENINGKATKAN KEMAMPUAN BERPIKIR KRITIS MATEMATIK SISWA MTS DENGAN MENGGUNAKAN METODE BRAIN-BASED LEARNING
}

\author{
Sri Solihah \\ Universitas Galuh Ciamis \\ Email: srisolihah1@gmail.com
}

\begin{abstract}
ABSTRAK
Penelitian ini dilatarbelakangi oleh kenyataan yang menunjukkan kemampuan berpikir kritis matematik siswa yang belum sesuai dengan yang diharapkan. Salah satu permasalahan tersebut adalah pembelajaran yang tidak memberikan keleluasaan kepada siswa untuk mengeksploitasi potensi otak secara optimal, dimana umumnya lebih menekankan pada fungsi otak kiri. Tetapi, keterampilan berpikir kritis matematik perlu didukung oleh fungsi otak kanan. Karakteristik pembelajaran yang menawarkan konsep belajar yang menyelaraskan cara kerja otak yang dirancang alami adalah Brain-Based Learning (BBL). Metode penelitian yang digunakan adalah quasi experiment. Data kuantitatif diperoleh dari hasil pretest dan posttest. Berdasarkan hasil penelitian menunjukan bahwa pencapaian dan peningkatan kemampuan berpikir kritis matematis siswa yang pembelajarannya menggunakan pendekatan Brain-Based Learning lebih baik daripada siswa yang pembelajarannya menggunakan pendekatan konvensional ditinjau secara keseluruhan dan berdasarkan KAM ( kelompok tinggi, sedang dan rendah).
\end{abstract}

Kata Kunci: Kemampuan berpikir kritis matematik, Model brain-based learning (BBL) 


\section{PENDAHULUAN}

Kemampuan berpikir kritis matematik merupakan kemampuan yang sangat esensial untuk kehidupan dan pekerjaan, serta berfungsi efektif dalam semua aspek kehidupan lainnya terutama di dalam pembelajaran matematik. Berpikir kritis telah lama menjadi tujuan pokok dalam pendidikan dan seringkali menjadi topik pembicaraan pada penelitian. Definisi berpikir kritis banyak dikemukakan oleh para ahli, salah satunya menurut pendapat (Sumarmo, 2013) yang mengemukakan bahwa berpikir kritis memuat kemampuan menetapkan sumber yang dapat dipercaya, membedakan antara suatu atau data yang relevan dan data yang tidak relevan, mengidentifikasi dan menganalisis asumsi, mengidentifikasi bias dan pandangan, dan mengakses bukti. Ennis (Williawati, 2009) mengemukakan definisi berpikir kritis adalah berpikir secara beralasan dan reflektif dengan menekankan kepada pembuatan keputusan tentang apa yang harus dipercayai atau dilakukan.

Senada dengan pendapat ahli yang telah dipaparkan sebelumnya, jenis soal untuk berpikir kritis dapat dihubungkan dengan taksonomi Bloom. Gokhale (Hendriana \& Soemarmo, 2017) mendefinisikan soal berfikir kritis sebagai soal yang melibatkan analisis, sintesis, dan evaluasi dari suatu konsep.Kemampuan berpikir kritis sangat penting dalam proses pembelajaran. Terdapat beberapa alasan yang mendasari pendapat tersebut, pertama termuat dalam kurikulum dan tujuan pembelajaran matematika, antara lain : berpikir logis, sistematis, kritis, kreatif,dan cermat serta berpikir objektif; kedua dalam berpikir kritis seseorang tidak mudah menerima sesuatu yang diterimanya, tanpa mengetahui asalnya, namun ia dapat mempertanggung jawabkan pendapatnya disertai alasan yang logis (Hendriana, Rohaeti \& Sumarmo, 2017); dan ketiga menurut pendapat Bayer (Sumarmo, 2013) mengemukakan bahwa berpikir kritis memuat kemampuan menetapkan sumber yang dapat dipercaya, membedakan antara suatu atau data yang relevan dan data yang tidak relevan, mengidentifikasi dan menganalisis asumsi, mengidentifikasi bias dan pandangan, dan mengakses bukti.

Berdasarkan uraian yang telah dipaparkan, dapat disimpulkan bahwa kemampuan berpikir kritis adalah kemampuan menggunakan logika untuk membuat, menganalisis, mengevaluasi serta mengambil keputusan tentang apa yang diyakini dan dilakukan. Indikator yang digunakan dalam penelitian ini adalah indikator berpikir kritis yaitu :

1. Mencari alternatif.

2. Menganalisis dan mengevaluasi argumen.

3. Memusatkan pada satu pertanyaan.

4. Mengenal asumsi-asumsi dan nilai-nilai yang tidak dinyatakan.

Berdasarkan hasil pengamatan yang dilakukan di kelas VII MTsN 2 Ciamis bahwa didalam pembelajaran matematika masih ada beberapa permasalahan. Permasalahan pertama adalah ratarata hasil belajar matematika siswa kelas VII MTsN 2 Ciamis belum mencapai nilai KKM. Kedua, pembelajaran yang dilakukan cenderung menggunakan model pembelajaran konvensional dimana proses yang terjadi lebih kepada ceramah dan memberikan latihan soal yang lebih menekankan fungsi otak kanan serta kurangnya mengoptimalkan fungi otak kiri. Ketiga, siswa cenderung pasif, bosan, tidak sedikit siswa mengobrol pada saat proses pembelajaran.

Masalah yang masih ada dalam dunia pendidikan adalah masih banyak siswa atau sebagian siswa menganggap matematika adalah pelajaran yang sulit dan tidak menarik serta belum merasakan manfaat mempelajari matematika. Hal tersebut dikarenakan pembelajaran matematika lebih didominasi oleh upaya menyelesaikan materi pelajaran bukan untuk membuat peserta didik mengerti dan paham dengan materi yang dipelajari, sehingga kurang memperhatikan kemampuan berpikir kritis (Asikin, 2002). Guru seharusnya dapat membuat suasana belajar menjadi menarik dan menyenangkan, oleh sebab itu diperlukan inovasi - inovasi dari guru untuk menarik minat belajar

Dikirim: 28 Februari 2019; Direvisi: 26 Maret 2019; Diterima: 26 Maret 2019

Cara sitasi: Solihah, S. 2019. Meningkatkan Kemampuan Berpikir Kritis Matematik Siswa MTs dengan Menggunakan Metode Brain-Based Learning. Jurnal Teorema: Teori dan Riset Matematika. Vol 4 No 1, Hal 55-64, Maret 2019. 
siswa dengan harapan siswa memiliki semangat dalam menerima setiap materi yang akan diberikan. Dengan semangat yang tumbuh dari siswa, akan berpengaruh pada hasil belajar siswa.

Untuk mengurangi ketimpangan tersebut diperlukan suatu inovasi pembelajaran agar apa yang diharapkan dalam proses pembelajaran yaitu siswa terlibat aktif sehingga dampaknya akan terlihat pada ingatan siswa tentang apa yang dipelajari dan ingatan itu akan bertahan lama. Menurut Sunaryo, Nuraida, \& Zakiah (2018) menyatakan bahwa "Pengembangan pembelajaran harus membuat siswa menjadi lebih mudah dalam memahami materi yang diajarkan". Untuk mewujudkan siswa menjadi aktif dan memiliki kemampuan berpikir kritis matematik yang lebih baik, tentu dibutuhkan pendekatan pembelajaran yang dapat mengeksplorasi dan melibatkan siswa secara aktif dan kreatif. Salah satu pendekatan pembelajaran yang dimaksud adalah pendekatan pembelajaran Brain-Based Learning.

Model BBL merupakan salah satu model yang efektif sehingga dapat mempengaruhi hasil belajar siswa, respon siswa, dan keaktifan siswa di kelas. Menurut (Jensen, 2008) Pembelajaran berbasis kemampuan otak mempertimbangkan apa yang sifatnya alami bagi otak kita dan bagaimana otak dipengaruhi oleh lingkungan dan pengalaman. Jadi, Brain-Based Learning adalah pembelajaran yang berdasarkan cara kerja otak. Saat otak bekerja dengan optimal, maka pada saat itu pembelajaran yang efektif dapat dilaksanakan. Pembelajaran dilakukan untuk menantang kemampuan berpikir siswa yang didukung oleh pembelajaran yang menyenangkan dan dengan siswa yang secara aktif terlibat dalam pembelajaran.

Sejalan dengan pendapat Awolola (2011), Brain-Based Learning adalah pembelajaran yang berpusat pada siswa dan guru hanya sebagai fasilitator yang mendukung kognitif siswa. Hal ini berarti dalam pembelajaran Brain-Based Learning ditekankan kepada Student Centered. Dengan begitu, siswa bisa lebih aktif dalam proses pembelajaran di kelas sehingga dapat mengembangkan kemampuan komunikasi dan berpikir kritis matematis mereka.

Fungsi guru dalam pendekatan Brain-Based Learning adalah untuk membuat siswa berada dalam kondisi menyenangkan, nyaman dan berada dalam kondisi perasaan positif dalam menerima pembelajaran. Melalui pembelajaran ini guru memberikan soal-soal yang menantang tingkat berpikir siswa dengan cara-cara yang menyenangkan. Pendekatan pembelajaran ini juga diharapkan dapat meningkatkan kepercayaan diri dan keberanian siswa di kelas. Dalam proses pembelajarannya diharapkan siswa tidak takut bertanya, tidak takut salah dan tidak takut untuk mencoba. Siswa diharapkan secara alami senang pada kondisi belajar dan secara alami menginginkan belajar.

Ada yang perlu diperhatikan dalam menetapkan prinsip Brain-Based Learning yang dapat berpengaruh terhadap pembelajaran menurut Jensen (2009) yaitu :

1. Lingkungan yang optimal

Otak akan bekerja secara optimal ketika dia menemukan lingkungan yang optimal pula. Otak akan menyerap informasi secara sadar atau tidak sadar akan lingkungan yang berada disekitarnya. Lingkungan akan menjadi salah satu pendukung dalam pembelajaran yang optimal. Pemilihan tempat duduk siswa, ruangan, media atau gambar di ruangan, aroma ruangan, dan sesuatu yang diperdengarkan akan membantu menciptakan pembelajaran yang optimal bagi siswa. Seringkali lingkungan sekitar tidak dihiraukan dalam pembelajaran. Namun, justru lingkungan sekitar merekalah yang dapat mempengaruhi kenyamanan pembelajaran.

2. Relaksasi

Dalam pembelajaran, relaksasi dibutuhkan pengoptimalan otak. Semakin besar tekanan yang siswa alami, semakin timbul kecemasan dalam diri siswa. Dengan kata lain, sistem saraf yang relaks adalah yang terbaik bagi pembelajaran. Relaksasi yang diberikan disela-sela pembelajaran dapat menurunkan stres yang dialami oleh siswa.

Dikirim: 28 Februari 2019; Direvisi: 26 Maret 2019; Diterima: 26 Maret 2019

Cara sitasi: Solihah, S. 2019. Meningkatkan Kemampuan Berpikir Kritis Matematik Siswa MTs dengan Menggunakan Metode Brain-Based Learning. Jurnal Teorema: Teori dan Riset Matematika. Vol 4 No 1, Hal 55-64, Maret 2019. 


\section{Musik}

Musik adalah aspek penting pada kehidupn manusia. Clynes (Jensen, 2009) menjelaskan bagaimana musik melibatkan seluruh bagian otak serta dapat mengoptimalkan cara kerja otak. Musik dapat berpengaruh terhadap suasana hati dan mengurangi setress. Beberapa suara dan musik dapat menghasilkan kondisi pembelajaran secara optimal, sekaligus juga dapat mengenergikan tubuh untuk mencapai kebugaran yang optimis. Dari penjelasan tersebut dapat disimpulkan bahwa musik dapat menjadi perananan yang penting dalam pelaksanaan pembelajaran yang optimal.

4. Emosi

Emosi adalah sumber informasi yang sangat penting dalam proses belajar mengajar. Emosi yang baik membuat otak lebih terstimulus untuk mengingat dan menginformasikan sesuatu dengan mudah. Pentingnya menjaga emosi yang stabil memiliki peranan yang optimal dengan unsur - unsur yang lain.

5. Nutrisi

Nutrisi yang baik menunjang peranan kerja neuron yang sehat. Oleh karena itu, guru semestinya mengingatkan para siswa untuk memperhatikan asupan nutrisi. Selain itu, berikan kebebasan siswa untuk membawa botol minum dan meminumnya di dalam kelas. Seringkali nutrisi menjadi hal yang terabaikan, karena guru tidak dapat mengontrol asupan nutrisi apa saja yang masuk dalam tubuh siswa.

Adapun langkah-langkah model Brain-Based Learning menurut Jensen (2008) terdiri dari tujuh tahap, yaitu:

1. Pra-pemaparan: tahap ini memberikan ulasan kepada siswa tentang pembelajaran baru sebelum benar-benar didalami lebih jauh. Pra-pemaparan berfungsi untuk membantu otak mengembangkan peta konseptual yang lebih baik dan menyiapkan konsentrasi belajar siswa.

2. Persiapan: tahap ini guru harus menciptakan keingintahuan dan kesenangan pada diri siswa.

3. Inisiasi dan akuisi: tahap ini merupakan tahap penciptaan koneksi. Tahap ini membantu siswa untuk membangun pengetahuan dan pemahaman awal.

4. Elaborasi: tahap ini memberikan kesempatan kepada otak siswa untuk menyortir, menyelidiki, menganalisis dan memperdalam pelajaran. Singkatnya tahap ini adalah tahap pemrosesan informasi.

5. Inkubasi dan memasukkan memori: tahap ini menekankan pentingnya waktu istirahat dan waktu untuk mengulang kembali, hal ini dikarenakan otak belajar paling efektif dari waktu ke waktu, bukan langsung pada sesaat.

6. Verifikasi dan pengecekan keyakinan: tahap ini guru mengecek pemahaman siswa dengan materi yang telah di pelajari.

7. Perayaan dan integrasi: tahap ini menanamkan semua arti penting dari kecintaan terhadap belajar.

Dari langkah-langkah Pendekatan Brain-Based Learning tersebut dapat disimpulkan bahwa Pendekatan Brain-Based Learning merupakan pembelajaran yang mengoptimalkan potensi otak siswa melalui strategi dan tahap yang telah ditentukan. Saat otak bekerja dengan optimal, maka pada saat itu pembelajaran yang efektif dapat dilaksanakan. Pembelajaran dilakukan untuk menantang kemampuan berpikir siswa yang didukung oleh pembelajaran yang menyenangkan dan dengan siswa yang secara aktif terlibat dalam pembelajaran. Penelitian ini juga menggunakan BrainBased Learning dengan tahapan yang dikemukakan oleh Jensen (2008) dengan tujuh tahapan pembelajaran sebagaimana yang telah dijelaskan.

Dikirim: 28 Februari 2019; Direvisi: 26 Maret 2019; Diterima: 26 Maret 2019

Cara sitasi: Solihah, S. 2019. Meningkatkan Kemampuan Berpikir Kritis Matematik Siswa MTs dengan Menggunakan Metode Brain-Based Learning. Jurnal Teorema: Teori dan Riset Matematika. Vol 4 No 1, Hal 55-64, Maret 2019. 


\section{METODE PENELITIAN}

Jenis penelitian yang diterapkan pada penelitian ini adalah penelitian eksperimen semu (quasi experiment). Ada perlakuan khusus pada kelas eksperimen yaitu pembelajaran dengan menggunakan pendekatan Brain-Based Learning sedangkan pada kelas kontrol menggunakan pendekatan konvensional. Desain yang digunakan dalam penelitian ini adalah sebagai berikut (Ruseffendi, 2015):

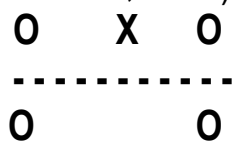

Keterangan:

0 : Pretes dan Postes Kemampuan berpikir kritis matematik siswa.

$X$ : Pembelajaran matematika dengan menggunakan pembelajaran Brain-Based Learning

... . : Pengambilan sampel tidak acak subyek

Populasi dalam penelitian ini adalah siswa kelas VIII disalah satu sekolah di kabupaten Ciamis pada tahun ajaran 2017-2018 yang terdiri dari tujuh kelas. Peneliti mengambil tujuh subyek populasi menjadi dua subyek eksperimen dan dua subyek non eksperimen, kemudian dari dua subyek yang terpilih sebagai kelas eksperimen tersebut dipilih kembali secara tidak acak untuk menentukan perlakuan mana (pendekatan Brain-Based Learning atau konvensional) yang akan dilaksanakan pada kelas-kelas tersebut. Diperoleh satu kelas subyek yang menggunakan pendekatan pembelajaran Brain-Based Learning yaitu kelas VIII-D dan satu kelas yang menggunakan pendekatan pembelajaran Konvensional yaitu kelas VIII-E. Alasan pemilihan subjek sampel adalah disesuaikan dengan karakteristik siswa yang sudah dapat bekerjasama antara siswa yang satu dengan yang lainnya yang sesuai dengan model Brain-Based Learning.

\section{HASIL DAN PEMBAHASAN}

Berdasarkan pengolahan data pretes dan postes kemampuan berpikir kritis matematik diperoleh skor rerata $(\bar{x})$ berikut presentase dari skor ideal (\%) dan standar deviasi (s) yang disajikan pada Tabel 1.

Tabel 1. Deskripsi Statistik Data Kemampuan Berpikir kritis Matematis Siswa Berdasarkan Kemampuan Awal Matematis

\begin{tabular}{|c|c|c|c|c|c|c|c|c|}
\hline \multirow{3}{*}{$\begin{array}{l}\text { Jenis } \\
\text { Kemampuan }\end{array}$} & \multirow{3}{*}{ KAM } & \multirow{3}{*}{$\begin{array}{l}\text { Data } \\
\text { Stat. }\end{array}$} & \multicolumn{6}{|c|}{ Kelas Penelitian } \\
\hline & & & \multicolumn{3}{|c|}{ Eksperimen } & \multicolumn{3}{|c|}{ Kontrol } \\
\hline & & & Pretes & Postes & $\langle g\rangle$ & pretes & postes & $\langle g\rangle$ \\
\hline \multirow{5}{*}{ 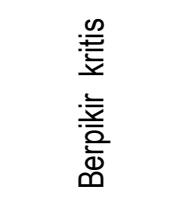 } & \multirow{3}{*}{ Tinggi } & $\overline{\bar{x}}$ & 5.00 & 16,33 & 0.75 & 5 & 14 & 0.47 \\
\hline & & $S$ & 2 & 0,58 & 0.01 & 0,82 & 1,15 & 0.22 \\
\hline & & $n$ & 3 & 3 & 3 & 4 & 4 & 4 \\
\hline & \multirow{3}{*}{ Sedang } & $\overline{\bar{x}}$ & 4 & 12 & 0,50 & 4,50 & 12 & 0.55 \\
\hline & & $S$ & 1.41 & 1,40 & 0.04 & 0,71 & 1,41 & 0.02 \\
\hline \multirow{5}{*}{ 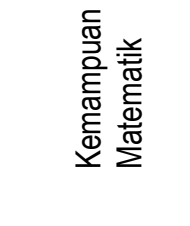 } & & $n$ & 2 & 2 & 2 & 2 & 2 & 2 \\
\hline & \multirow{3}{*}{ Rendah } & $\overline{\bar{x}}$ & 3.89 & 11,14 & 0.45 & 3,78 & 9,52 & 0.34 \\
\hline & & $S$ & 0,96 & 2,38 & 0.14 & 1,08 & 1,89 & 0.12 \\
\hline & & $N$ & 28 & 28 & 28 & 27 & 27 & 27 \\
\hline & Total & & 4,00 & 11,67 & 0,48 & 4 & 9,97 & 0,37 \\
\hline
\end{tabular}

Untuk pencapaian kemampuan berpikir kritis matematis siswa MTs yang pembelajarannya menggunakan pendekatan Brain-Based Learning dan pendekatan konvensional menunjukan 
perbedaan secara keseluruhan, pencapaian kemampuan berpikir kritis matematis siswa MTs menggunakan pembelajaran pendekatan Brain-Based Learning dengan $\bar{x}=11,67$ (58,33\%) lebih tinggi dibandingkan dengan pembelajaran Konvensional $\bar{x}=9,97$ (49,85\%).

\section{Gambar 1. Diagram Batang Rataan Kemampuan Berpikir Kritis Matematis Berdasarkan KAM}

Untuk KAM tinggi dan KAM rendah, pencapaian kemampuan berpikir kritis matematis siswa MTs yang pembelajarannya menggunakan pendekatan Brain-Based Learning lebih tinggi dibandingkan siswa yang pembelajarannya menggunakan pendekatan konvensional, namun berbeda dengan KAM sedang pencapaian kemampuan berpikir kritis matematis siswa MTs yang pembelajarannya menggunakan pendekatan Brain-Based Learning sama dengan siswa yang pembelajarannya menggunakan pendekatan konvensional.

Uji Homogenitas digunakan untuk mengetahui apakah data berasal dari kelompok yang memiliki varians yang sama antara kedua kelas tersebut atau tidak. Uji homogenitas yang digunakan dalam penelitian ini adalah uji t dengan mengambil taraf signifikasi $5 \%$.

\section{Tabel 2. Uji Homogenitas Data Postes Berpikir Kritis Matematis}

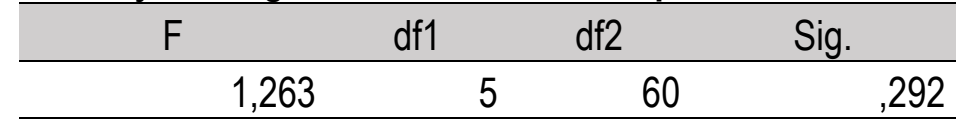

a. Design: Intercept + KAM + Pembelajaran + KAM *

Pembelajaran

Berdasarkan data pada Tabel 2 terlihat bahwa Sig. adalah 0,292 sehingga nilai tersebut memenuhi kriteria Sig. > 0,05 maka Ho diterima yang artinya data berasal dari sampel yang homogen. Dikarenakan data berasal dari sampel yang homogen maka selanjutnya dilakukan pengujian statistik dengan uji t. Berikut ini disajikan pada Tabel 3 hasil pengolahan data uji t kelas eksperimen dan kelas Kontrol. 
Tabel 3. Uji t Postes Kemampuan Berpikir Kritis Matematis

\begin{tabular}{|c|c|c|c|c|}
\hline \multirow{2}{*}{\multicolumn{2}{|c|}{  }} & \multicolumn{2}{|c|}{$\begin{array}{c}\text { Levene's Test for Equality of } \\
\text { Variances }\end{array}$} & \multirow{2}{*}{$\begin{array}{c}\text { t-test for Equality of } \\
\text { Means } \\
\text { Sig. (2-tailed) }\end{array}$} \\
\hline & & $\mathrm{F}$ & Sig. & \\
\hline \multirow[t]{2}{*}{ Postes } & Equal variances assumed & 840 & ,363 &, 007 \\
\hline & Equal variances not assumed & & & 007 \\
\hline
\end{tabular}

Berdasarkan Tabel 3 menunjukan bahwa peningkatan kemampuan berpikir kritis matematis siswa sebesar 0,007 artinya pencapaian kemampuan komunikasi matematik siswa yang pembelajarannya menggunakan pendekatan Brain-Based Learning lebih baik daripada siswa yang pembelajarannya menggunakan pendekatan konvensional.

Sedangkan untuk tingkatan KAM (tinggi dan rendah) n-Gain kemampuan berpikir kritis matematis siswa yang pembelajarannya menggunakan pendekatan Brain-Based Learning lebih tinggi dibandingkan siswa yang pembelajarannya menggunakan pendekatan konvensional namun pada KAM n-Gain kemampuan berpikir kritis matematis yang mempunyai KAM sedang untuk pembelajaran Brain-Based Learning lebih rendah dibandingkan dengan $\mathrm{n}$-Gain pembelajaran Konvensional namun tidak terlalu signifikan dan masih tergolong rendah.

Seperti telah diketahui bahwa kelompok sampel penelitian dikelompokan berdasarkan KAM sehingga ukuran sampelnya kecil dan ada yang tidak terdeteksi oleh normalitas. Menurut Ruseffendi (2005) jika ukuran sampel kecil dan tidak dapat menguji normalitasnya maka dilakukan uji nonparametrik. Uji nonparametrik yang digunakan adalah uji Kruskal-Wallis 1-way ANOVA (k sampel) yang disajikan pada Tabel 4.

\section{Tabel 4. Uji Kruskall-Wallis Kemampuan Berpikir Kritis Matematik Berdasarkan Pendekatan Pembelajaran dan Kemampuan Awal Matematika Hypothesis Test Summary}

\begin{tabular}{|c|c|c|c|c|}
\hline & Null Hypothesis & Test & Sig. & Decision \\
\hline 1 & $\begin{array}{l}\text { The distribution of Postes is the } \\
\text { same across categories of KAM. }\end{array}$ & $\begin{array}{l}\text { Independent- } \\
\text { Samples } \\
\text { Kruskal- } \\
\text { Dillis Test }\end{array}$ & .002 & $\begin{array}{l}\text { Reject the } \\
\text { null } \\
\text { hypothesis. }\end{array}$ \\
\hline
\end{tabular}

Asymptotic significances are displayed. The significance level is ,05.

Berdasarkan pada Tabel 4 diperoleh nilai Sig. 0,002 atau kata lain Sig. $<0,05$, hal tersebut dapat disimpulkan bahwa paling tidak terdapat satu kelompok siswa dengan KAM tertentu yang hasil belajar matematika siswanya berbeda secara signifikan dengan KAM lainnya pada taraf signifikasi $5 \%$.

Untuk mengetahui kelompok siswa dengan KAM mana yang berbeda secara signifikan dalam hasil belajar matematika dapat dilihat pada Tabel 5 .

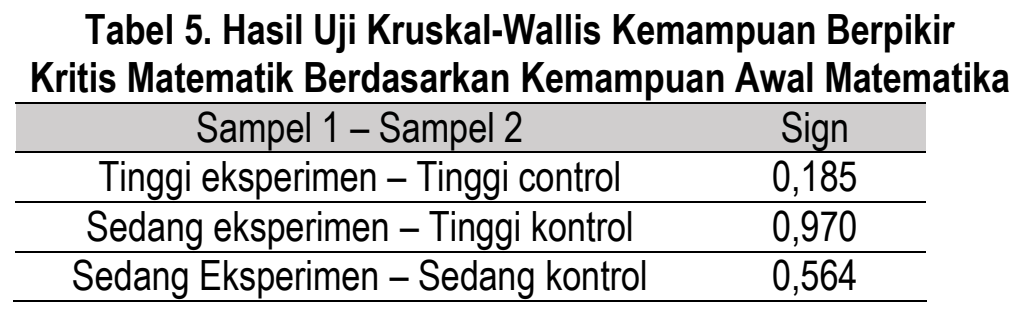

Dikirim: 28 Februari 2019; Direvisi: 26 Maret 2019; Diterima: 26 Maret 2019

Cara sitasi: Solihah, S. 2019. Meningkatkan Kemampuan Berpikir Kritis Matematik Siswa MTs dengan Menggunakan Metode Brain-Based Learning. Jurnal Teorema: Teori dan Riset Matematika. Vol 4 No 1, Hal 55-64, Maret 2019. 


\begin{tabular}{cc}
\hline Sampel 1 - Sampel 2 & Sign \\
\hline Rendah eksperimen - Sedang kontrol & 0,556 \\
\hline Rendah eksperimen - Rendah kontrol & 0,011 \\
\hline
\end{tabular}

Berdasarkan data pada Tabel 5 terlihat bahwa KAM rendah eksperimen terhadap rendah kontrol mempunyai nilai Sig. adalah 0,011 sehingga nilai tersebut memenuhi kriteria $\leq 0,05$, maka dapat diartikan bahwa pencapaian kemampuan komunikasi matematik KAM rendah yang pembelajarannya menggunakan pendekatan Brain-Based Learning lebih baik daripada KAM rendah yang pembelajarannya dengan menggunakan pendekatan konvensional. Tabel 6 .

Begitu pula untuk $n$-Gain kemampuan berpikir kritis matematik dapat diperoleh data pada

\section{Tabel 6. Uji Kruskall-Wallis n-Gain Kemampuan Berpikir Kritis Matematik Berdasarkan Pendekatan Pembelajaran dan Kemampuan Awal Matematika}

\section{Hypothesis Test Summary}

\begin{tabular}{|c|c|c|c|c|}
\hline & Null Hypothesis & Test & Sig. & Decision \\
\hline 1 & $\begin{array}{l}\text { The distribution of nGain is the } \\
\text { same across categories of KAllul. }\end{array}$ & $\begin{array}{l}\text { Independent- } \\
\text { Samples } \\
\text { Krułal- } \\
\text { viollis Test }\end{array}$ & .003 & $\begin{array}{l}\text { Reject the } \\
\text { null } \\
\text { hypothesis. }\end{array}$ \\
\hline
\end{tabular}

Asymptotic significances are displayed. The significance level is .05.

Berdasarkan pada Tabel 6 diperoleh nilai Sig. 0,003 atau kata lain Sig. $<0,05$, hal tersebut dapat disimpulkan bahwa paling tidak terdapat satu kelompok siswa dengan KAM tertentu yang hasil belajar matematika siswanya berbeda secara signifikan dengan KAM lainnya pada taraf signifikasi $5 \%$.

Untuk mengetahui kelompok siswa dengan KAM mana yang berbeda secara signifikan dalam hasil belajar matematika dapat dilihat pada Tabel 7 .

Tabel 7. Hasil Uji Kruskal-Wallis n-Gain Kemampuan Berpikir Kritis Matematik
\begin{tabular}{cc}
\hline \multicolumn{2}{c}{ Berdasarkan Kemampuan Awal Matematika } \\
\hline Sampel 1 - Sampel 2 & Sign \\
\hline Tinggi eksperimen - Tinggi control & 0,143 \\
\hline Sedang eksperimen - Tinggi kontrol & 0,827 \\
\hline Sedang Eksperimen - Sedang kontrol & 0,744 \\
\hline Rendah eksperimen - Sedang kontrol & 0,821 \\
\hline Rendah eksperimen - Rendah kontrol & 0,009 \\
\hline
\end{tabular}

Berdasarkan data pada Tabel 7 terlihat bahwa KAM rendah eksperimen terhadap rendah kontrol mempunyai nilai Sig. adalah 0,009 sehingga nilai tersebut memenuhi kriteria $\leq 0,05$, maka dapat diartikan bahwa pencapaian kemampuan berpikir kritis matematik KAM rendah yang pembelajarannya menggunakan pendekatan Brain-Based Learning lebih baik daripada KAM rendah yang pembelajarannya dengan menggunakan pendekatan konvensional.

\section{KESIMPULAN}

Berdasarkan hasil penelitian yang telah dilakukan untuk meningkatkan kemampuan komunikasi dan berpikir kritis matematis siswa MTs yang pembelajarannya menggunakan pendekatan Brain-Based Learning dapat disimpulkan bahwa: 
1. Pencapaian dan peningkatan kemampuan berpikir kritis matematis siswa yang pembelajarannya menggunakan pendekatan Brain-Based Learning lebih baik daripada siswa yang pembelajarannya menggunakan pendekatan konvensional ditinjau secara keseluruhan dan berdasarkan KAM ( kelompok tinggi, sedang dan rendah).

2. Kesulitan siswa dalam menyelesaikan soal kemampuan berpikir kritis matematis yaitu memusatkan pada satu pertanyaan dan mengenal asumsi-asumsi dan nilai-nilai yang tidak dinyatakan.

3. Pendapat siswa terhadap pembelajaran dengan menggunakan pendekatan Brain-Based Learning menunjukan sikap yang positif pada saat pembelajaran berlangsung.

\section{REKOMENDASI}

Berdasarkan penelitian dan pembahasan penulis memberikan beberapa saran :

1. Pembelajaran dengan pendekatan Brain-Based Learning dapat meningkatkan kemampuan berpikir kritis matematik siswa dibandingkan dengan pembelajaran konvensional maka disarankan pembelajaran menggunakan pendekatan Brain-Based Lerning diterapkan pada topik-topik matematika yang lain.

2. Dalam pembelajaran matematika penerapan pendekatan Brain-Based Learning hendaknya dapat dijadikan sebagai salah satu alternatif pendekatan pembelajaran dalam mengembangkan pembelajaran matematika dikelas untuk meningkatkan keaktifan siswa dan melatih keberanian siswa dalam bertanya dan menjawab.

\section{UCAPAN TERIMAKASIH}

Penulis mengucapkan terimakasih kepada Drs. Kuswendi selaku kepala sekolah di tempat penelitian sehingga telah mendukung dan membimbing dalam penelitian ini hingga penulis dapat melakukan penelitian dengan lancar.

\section{DAFTAR PUSTAKA}

Asikin, M. (2002). Dasar Proses Pebelajaran Matematik1. Jakarta: Reneka Cipta.

Awalola. (2011). Effect of Brain-Based Learning Strategy on Student's Achievement in Senior Secendary School Mathematics in Oyo State Nigeria. Cypriot Journal of Educational Science, 2: $91-106$.

Hendriana, H., \& Sumarmo, U. (2017). Penilaian Pembelajaran Matematika Edisi Revisi. Bandung: Rafika Aditama.

Hendriana, Rohaeti, \& Sumarmo. (2017). Hard Skills dan Soft Skills Matematik Siswa. Bandung: Rafika Utama.

Jensen, E. (2008). Brain-Based Learning Pembelajaran Berbasis Kemampuan Otak Cara Baru dalam Pembelajaran dan Pelatihan. Jogjakarta: Pustaka Pelajar.

Jensen, E. (2009). Brain-Based Learning Edisi Revisi (Revisi). Yogyakarta: Pustaka Pelajar.

Ruseffendi, H. E. T. (2015). Dasar-Dasar Penelitian Pendidikan dan Bidang Non-Eksakta Lainnya. Bandung : Tarsito.

Sumarmo. (2013). Berpikir dan Disposisi Matematik serta Pembelajarannya. Bandung: FPMIPA UPI.

Dikirim: 28 Februari 2019; Direvisi: 26 Maret 2019; Diterima: 26 Maret 2019

Cara sitasi: Solihah, S. 2019. Meningkatkan Kemampuan Berpikir Kritis Matematik Siswa MTs dengan Menggunakan Metode Brain-Based Learning. Jurnal Teorema: Teori dan Riset Matematika. Vol 4 No 1, Hal 55-64, Maret 2019. 
•64 Jurnal Teorema: Teori dan Riset Matematika Vol 4 No 1, Hal 64-64, Maret 2019

Sunaryo, Y., Nuraida, I., dan Zakiah, N. E. (2018). Pengaruh Model Pembelajaran Hybrid Tipe Traditional Clasess-Real Workshop terhadap Kemampuan Pemahaman Matematik Ditinjau dari Self-Confidence Siswa. Teorema: Teori dan Riset Matematika, Vol 2, No 2. 93100.

Williawati, L. (2009). Pengaruh Pembelajaran Matematika dengan Pendekatan Diskursus terhadap Kemampuan Berpikir Kritis Siswa dalam Matematika. UNPAS. 